\title{
PENDIDIKAN RESPONSIF GENDER BAGI ANAK USIA DINI
}

Oleh:

Susilo Setyo Utomo ${ }^{1}$, Uni Ekowati ${ }^{2}$

\begin{abstract}
Abstrak
Artikel ini bertujuan untuk mengetahui model pendidikan responsif gender bagi anak-anak. Beberapa tahun terakhir ini kajian masalah perempuan dan gender di Indonesia menunjukkan perkembangan yang cukup pesat sekaligus merefleksikan meningkatnya kesadaran berbagai kalangan termasuk kalangan yang bergerak dalam dunia pendidikan. Tujuan dari pendidikan responsif gender yaitu terwujudkan kesetaraan gender sebagai upaya pemahaman agar peserta didik dapat memahami dalam memposisikan peran seorang perempuan maupun peran lakilaki. Penelitian ini merupakan penelitian kualitatif deskriptif. Lokasi dalam penelitian ini di Taman Kanak-Kanak yang ada di Kota Kupang, Nusa Tenggara Timur (NTT). Penentuan informan dalam penelitian ini dilakukan secara purposive sampling. Teknik pengumpulan data yang dipakai adalah melalui wawancara, observasi, dan studi dokumen, dan pustaka. Hasil penelitian menunjukkan bahwa pendidikan responsif gender bagi anak-anak dapat dilakukan melalui pendidikan dan pendekatan budaya, baik di sekolah maupun dalam keluarga.
\end{abstract}

Kata Kunci: Pendidikan responsive Gender, Perilaku Sosial, Anak Usia Dini

\footnotetext{
1 Program Studi Pendidikan Sejarah, Universitas Nusa Cendana, email: susilosetyoutomo@staf.undana.ac.id (Corresponding author)

${ }^{2}$ Program Studi Antropologi Sosial, Universitas Muhammadiyah Kupang
} 


\section{Pendahuluan}

Dalam pembangunan berbangsa, gender merupakan suatu strategi global yang berupaya untuk meningkatkan kepedulian akan aspirasi, kepentingan dan peranan perempuan dan laki-laki tanpa mengesampingkan harkat, kodrat dan martabat perempuan dan laki-laki dalam segala bidang. Proses pembangunan dan pengembangan manusia Indonesia melalui pendidikan tidak hanya terfokus kepada aspek pengetahuan dan intelektual anak, tetapi juga pembangunan dari aspek agama dan moral (akhlak). Dengan demikian pengembangan aspek-aspek tersebut diharapkan dapat terwujud manusia Indonesia seutuhnya. Artinya mereka menguasai tidak hanya ilmu pengetahuan dan teknologi tetapi juga menguasai sikap moral, mental dan spiritual yang baik pula.

Di Indonesia secara normative, Negara telah mengambil peran penting untuk memajukan perempuan di segala bidang sebagaimana tertera dalam pasal 28 ayat 1 UUD 1945 tentang Hak Asasi Manusia yang menyatakan setiap orang berhak mengembangkan diri melalui pemenuhan kebutuhan dasarnya, mendapatkan pendidikan dan memperoleh manfaat dari ilmu pengetahuan dan teknologi, seni serta budaya serta meningkatkan mutu hidup dan kesejahteraan umat manusia. Landasan hulum lain yang memastikan terciptanya kesetaraan gender adalah UU No.7 tahun 1984 tentang pengesahan Konvensi mengenai penghapusan segala bentuk diskriminasi terhadap perempuan dan Instruksi Presiden No.9 tahun 2000 tentang pengarusutamaan gender dalam kebijakan, program dan kelembagaan termasuk bidang pendidikan. Lebih khusus lagi UU No.20 tahun 2003 tentang sistem pendidikan nasional juga telah membuat beberapa paradigma baru yang lebih memberikan kesempatan seluas-luasnya bagi laki-laki dan perempuan untuk berpartisipasi dalam pendidikan.

Kesetaraan gender menjadi suatu program dan kegiatan yang diharapkan dapat meningkatkan derajat dan martabat baik perempuan dan laki-laki. Gender di era global berkaitan dengan kesadaran, tanggung jawab laki-laki, pemberdayaan perempuan termasuk hal reproduksi.

Kesetaraan gender sebagaimana dijelaskan di atas mencakup pula kesetaraan dalam pendidikan secara yuridis, dan kesetaraan tersebut dapat dilihat dalam ketentuan UU No. 20 Tahun 2003 tentang Sistem Pendidikan Nasional: "Pendidikan adalah usaha sadar dan terencana untuk mewujudkan suasana belajar dan proses belajar dan proses pembelajaran agar peserta didik secara aktif mengembangkan potensi dirinya untuk memiliki kekuatan spiritual keagamaan, pengendalian diri, 
kepribadian, kecerdsan, akhlak mulia serta ketrampilan yang diperlukan dirinya masyarakat, bangsa dan negara" (Ayat 1).

Pada pasal di atas menjelaskan bahwa adanya persamaan hak untuk memperoleh pendidikan baik bagi penduduk laki-laki maupun perempuan, selaian itu dalam UUD 1945 terutama dalam pasal 31 ayai 1 juga menyebutkan bahwa, "Setiap warga negara berhak mendapatkan pendidikan. Penjelasan Pasal tersebut mengandung makna bahwa setiap warga negara baik laki-laki maupun perempuan memiliki kesempatan yang sama untuk memperoleh pendidikan sehingga tidak boleh dan dilarang adanya tindakan diskriminasi baik pada laki-laki maupun pada perempuan dengan tujuan agar tercipta kesetaraan gender dalam bidang pendidikan.

Perhatian terhadap wacana gender utamanya di Indonesia dapat dikatakan relatif masih baru dan semakin berkembang dengan meningkatnya kesadaran kaum perempuan akan harkat kemanusiannya yang karena adanya tekanan dari akar budaya patriarki yang banyak diterapkan di berbawai wilayah di Indonesia. Dalam budaya patriarki hak-hak asasi manusia menjadi berkurang bahkan ada yang hilang sama sekali. Dalam beberapa tahun terakhir ini kajian masalah perempuan dan gender di Indonesia menunjukkan perkembangan yang cukup pesat sekaligus merefleksikan meningkatnya kesadaran berbagai kalangan termasuk kalangan yang bergerak dalam dunia pendidikan.

Pendidikan responsif gender dapat diselipkan melalui kurikulum yang responsif gender, sehingga ada bentuk perhatian terhadap hak-hal laki-laki maupun perempuan. Karena pendidikan berperspektif gender tidak hanya untuk perempuan saja tetapi juga untuk laki-laki. Di dalam kurikulum tersebut tertuang kesetaraan gender dalam aktivitas pembelajaran anak-anak sehari-hari, selain itu juga perlu adanya kesetaraan perlakuan pada semua peserta didik di dalam kelas maupun di luar kelas, termasuk perlakuan adil dalam proses pembelajaran. Dalam hal ini pemerintah sudah seharusnya mendukung kesetaraan gender dengan menyusun peraturan perundang-undangan yang berpihak pada kesetaran gender khusunya dalam bidang pendidikan. Harapan-harapan tersebut belum sepenuhnya terwujud dalam dunia pendidikan. Masih terdapat banyak kesenjangan antara laki-laki dan perempuan dalam dunia pendidikan. Untuk itulah diperlukan pendidikan responsif gender. 
Metode Penelitian

Jenis penelitian yang digunakan dalam penelitian ini yaitu deskriptif kualitatif. Menurut Moleong (2005:6) metode penelitian deskriptif kualitatif yaitu penelitian yang bermaksud untuk memahami fenomena empiris secara holistic (menyeluruh) dengan cara deskripsi dalam bentuk kata-kata dan bahasa, pada suatu konteks khusus dengan memanfaatkan berbagai metode ilmiah.

Lokasi dalam penelitian ini di Taman Kanak-Kanak (TK) yang ada di Kota Kupang, Nusa Tenggara Timur (NTT). Sesuai dengan judul penelitian yang ingin mengungkapkan pendidikan responsif gender bagi anak-anak

Penentuan informan dalam penelitian ini dilakukan secara purposive sampling. Menurut Sugiyono (2012:124) sampling purposive adalah teknik penentuan sampel dengan pertimbangan tertentu. Dalam hal ini peneliti menentukan informan yaitu kepala sekolah dan beberapa guru dengan pertimbangan bahwa mereka yang menguasai dan melaksanakan langsung proses pendidikan yang responsive gender. Sementara trianggulasi sumber dengan, orang tua peserta didik. Teknik pengumpulan data yang dipakai adalah melalui wawancara, observasi, dan studi dokumen, dan pustaka.

\section{Hasil dan Pembahasan}

Menurut UU RI No 2 tahun 2003 tentang Sistem Pendidikan Nasional, menegaskan bahwa pendidikan adalah usaha sadar dan terencana untuk mewujudkan suasana belajar dan proses pembelajaran agar peserta didik secara aktif mengembangkan potensi dirinya untuk memiliki kekuatan spiritual keagamaan, pengendalian diri, kepribadian, kecerdasan, akhlak mulia, serta keterampilan yang diperlukan dirinya, masyarakat, bangsa dan negara.

Pendidikan merupakan pilar tegaknya bangsa; Pendidikan mampu menjaga martabat bangsa Dalam UU 20/2003 tentang Sistem Pendidikan Nasional, Pasal 3, disebutkan "Pendidikan nasional berfungsi mengembangkan kemampuan dan membentuk watak serta peradaban bangsa yang bermartabat dalam rangka mencerdaskan kehidupan bangsa, bertujuan untuk berkembangnya potensi peserta didik agar menjadi manusia yang beriman dan bertakwa kepada Tuhan Yang Maha Esa, berakhlak mulia, sehat, berilmu, cakap, kreatif, mandiri, dan menjadi warga negara yang demokratis serta bertanggung jawab.

Menurut M.J Langeveld dalam Yunus (1999:7) pendidikan adalah setiap pergaulan yang terjadi antara seorang dewasa dengan anak-anak merupakan 
lapangan atau sesuatu keadaan dimana pekerjaan mendidik itu berlangsung.

Dengan demikian dapat disimpulkan bahwa pendidikan merupakan sarana untuk mendapatkan ilmu pengetahuan. Pendidikan bertujuan mengembangkan potensi peserta didik agar menjadi manusia yang beriman dan bertakwa kepada Tuhan Yang Maha Esa. Pendidikan dikatakan penting karena melalui pendidikan peserta didik mempersiapkan diri dimasa depan agar mampu bersaing di era global sesuai dengan tuntutan zaman. Oleh karena itu tidak hanya pemerintah tetapi semua elemen berupaya terus menerus dalam rangka meningkatkan kualitas pendidikan di Indonesia.

Menurut Riant Nugroho (2011:3) Gender merupakan perbedaan perilaku antara laki-laki dan perempuan yang dikontruksi secara sosial, yakni perbedaan yang bukan ketentuan Tuhan melainkan yang dicipatakan oleh manusia melalui proses sosial dan cultural yang panjang. Sedangkan di dalam Women's Studies Encyclopedya dijelaskan bahwa gender adalah suatu konsep cultural yang berupaya membuat pembedaan dalam hal peran, perilaku, mentalitas dan karakteristik emosional antara laki-laki dan perempuan yang berkembang dalam masyarakat (Umar, 2001:33).

Dalam memahami Konsep Gender Mansour Fakih (2013:9) membedakan antara gender dan (seks) jenis kelamin. Pengertian seks lebih condong pada pensifatan atau pembagian dua jenis kelamin manusia berdasarkan biologis yang melekat, tidak berubah dan tidak dapat ditukar. Dalam hal ini sering dikatakan sebagai ketentuan Tuhan atau"kodrat".

Menurut Mansour Fakih (2013:8) Gender adalah suatu sifat yang melekat pada kaum laki-laki atau perempuan yang dikonstruksi secara sosial maupun cultural dan dapat dipertukarkan. Seperti anggapan bahwa perempuan itu dikenal lembut, emosional dan keibuan. Sementara lakilaki dianggap kuat, rasional, jantan dan perkasa. Ciri dari sifat itu adalah merupakan sifat-sifat yang dapat dipertukarkan. Sehingga semua hal yang dapat dipertukarkan antara sifat laki-laki dan perempuan, yang bisa berubah dari waktu ke waktu, dari suatu tempat ke tempat lainnya maupun dari kelas ke kelas lainnya itulah yang disebut dengan gender.

Di Indonesia, kata gender bagi sebagian masyarakat masih diasumsikan sebagai segala persoalan yang identik dengan perempuan. Bahkan banyak orang 
yang tidak dapat membedakan antara gender dan seks. Kesalahan dalam memahami konsep gender tentu akan menimbulkan permasalahan bias gender. Gender secara umum yang lazim dikenal masyarakat digunakan untuk mengidentifikasi perbedaan laki-laki dan perempuan dari segi anatomi biologi (perbedaan komposisi kimia, hormone dalam tubuh, anatomi fisik, reproduksi dan karakteristik lainnya). Atas dasar itulah studi gender lebih menekankan kepada perkembangan aspek maskulinitas atau feminitas seseorang. Dengan kata lain mendefiniskikan laki-laki dan perempuan dari sudut non biologis (Mufidah, 2010:4).

Sedangkan menurut umar (2001:35) gender adalah suatu sifat yang melekat pada laki-laki atau perempuan yang dikontruksi secara sosial maupun cultural. Misalnya perempuan dikenal lemah lembut, cantik, emosional atau keibuan. Sementara laki-laki dianggap kuat, rasional, jantan dan perkasa. Ciri dari itu sendiri merupakan sifat-sifat yang dapat dipertarukan. Artinya ada laki-laki yang emosional, lemah lembut, keibuan, sementara itu ada juga perempuan yang kuat, rasional dan perkasa. Perubahan cirri dari sifat itu dapat terjadi dari waktu-ke waktu dan dari tempat ke tempat yang lainnya. Segala sesuatu yang dapat dipertukarkan antara sifat perempuan dan laki-laki, yang bisa berubah dari waktu ke waktu serta berbada dari tempat ke tempat lainnya adalah merupakan konsep gender.

Dengan demikian dapat disimpulkan bahwa gender adalah pembedaan peran, fungsi dan tanggung jawab antara perempuan dan laki-laki yang dihasilkan dari konstruksi sosial budaya dan dapat berubah sesuai dengan perkembangan zaman, sedangkan jenis kelamin adalah perbedaan antara laki-laki dan perempuan yang ditentukan oleh perbedaan biologis yang melekat pada keduanya. Menurut Wibowo (2010:193) pembelajaran responsive gender adalah proses pembelajaran yang memberikan perhatian seimbang bagi kebutuhan khusus laki-laki maupun perempuan.

Berdasarkan pengertian di atas dapat disimpulkan bahwa pendidikan responsive gender adalah pendidikan yang mengedepankan keterlibatan secara aktif antar jenis kelamin sehingga tidak ada batasan antara laki-laki dan perempuan. Tujuan dari pendidikan responsif gender yaitu terwujudkan kesetaraan gender sebagai upaya pemahaman agar peserta didik dapat memahami dalam memposisikan peran seorang perempuan maupun peran laki-laki

\section{Konsep Kesetaraan Dan Keadilan Gender}

Menurut Riant Nugroho (2011:29) Kesetaraan Gender adalah adanya 
kesamaan kondisi bagi laki-laki maupun perempuan dalam memperoleh kesempatan serta hak-haknya sebagai manusia, agar mampu berperan dan berpartisipasi dalam kegiatan politik, hukum, ekonomi, sosial budaya, pendidikan, dan pertahanan dan keamanan nasional (hankamnas) serta kesamaan dalam menikmati hasil pembangunan. Terwujudnya kesetaraan dan keadilan gender ditandai dengan tidak adanya diskriminasi antara perempuan dan lakilaki sehingga dengan demikian antara perempuan dan laki-laki memiliki akses, kesempatan berpartisipasi, dan kontrol atas pembangunan serta memperoleh manfaat yang setara dan adil dari pembangunan.

Sedangkan menurut Ratna Megawangi (1999:19) kesetaraan gender adalah seperti sebuah frase (istilah)'suci'yang sering diucapkan oleh para aktivis sosial, kaum feminis, politikus, bahkan hampir oleh pejabat Negara. Istilah kesetaraan gender dalam tataran praksis, hampir selalu diartikan sebagai kondisi "ketidaksetaraan" yang dialami oleh para wanita. Maka Istilah Kesetaraan gender sering terkait dengan istilah-istilah diskriminasi terhadap perempuan seperti; subordinasi, penindasan, kekerasan, dan semacamnya.
Menurut Dadang dkk (1997:32) Upaya-upaya yang paling tepat dilakukan untuk mensosialisasikan kesetaraan gender yaitu dengan cara:

1) Pembakuan istilah gender dengan acuan pada keberadaan segala sesuatu yang ada di masyarakat secara tradisi, dengan mempertimbangkan berbagai muatan sosial budaya, ekonomi, dan politik dalam konteks akses terhadap berbagai muatan pembangunan.

2) Pendekatan analisis gender tidak lagi sekadar merujuk pada pembedaan biologis atau seks (laki-laki atau perempuan) atau sifat perseorangan (maskulin-feminin) akan tetapi mengacu pada perspektif gender menurut dimensi sosial-budaya.

3) Perencanaan pembangunan perlu dilakukan dengan mempertimbangkan perbedaan peran gender dan ketergantungan antara laki-laki dan perempuan sebagai sesuatu hal yang dapat diubah dan akan mengalami perubahan sesuai dengan kondisi sosial-budaya masyarakat yang bersangkutan. Jika cara ini dilakukan maka dapat diharapkan proses pemudaran stereotip pembagian peran seks (biologis) yang bersifat rigid dapat berlangsung. 
Pengertian dari Keadilan gender Menurut Riant Nugroho (2011:29) merupakan suatu proses dan perlakuan adil terhadap kaum laki-laki dan perempuan. Dengan keadilan gender berarti tidak ada lagi pembakuan peran, beban ganda, subordinasi, marjinalisasi, dan kekerasan terhadap perempuan maupun laki-laki.

Menurut Mansour Fakih (2013:12) bahwa perbedaan gender sebenarnya bukan suatu masalah sepanjang tidak menimbulkan ketidakadilan gender (gender inequalities). Namun, yang menjadi masalah adalah ternyata perbedaan gender ini telah menimbulkan berbagai ketidakadilan, baik bagi kaum laki-laki dan utamanya terhadap perempuan. Secara biologis?(kodrat) kaum perempuan dengan organ reproduksinya dapat hamil, melahirkan dan menyusui kemudian muncul gender role? (peran gender) sebagai pengasuh dan pendidik anak. Dengan demikian, gender role dianggap tidak menimbulkan masalah dan tidak perlu digugat. Namun, yang menjadi masalah dan perlu dipertanyakan adalah struktur gender inequalities yang ditimbulkan oleh gender role dan Gender differences.

\section{Pentingnya Pendidikan Responsif}

\section{Gender Bagi Anak Usia Dini}

Anak merupakan salah satu subyek yang penting dalam pembangunan, karena anak merupakan generasi yang dapat dijadikan penerus dari pembangunan yang dilakukan saat ini. Sehingga anak juga berperan penting dalam proses pembangunan. Oleh karenanya anak sebagai generasi penerus bangsa yang harus dijaga. Penjagaan tersebut dapat diupayakan dalam bentuk pembiasaan terhadap lingkungan yang memulai nilainilai kesetaraan maupun keadilan gender.

Pendidikan responsif gender pada anak-anak dirasakan urgensinya demi mewujudkan kesetaraan dan keadilan gender di bidang pendidikan. Untuk itu pemberdayaan perempuan dalam bidang pendidikan harus dilakukan secara simultan agar perempuan dapat mengaktualisasikan dirinya sesuai dengan potensi yang mereka miliki.

Pendidikan merupakan kunci utama dalam rangka transfer knowledge, transfer of behavior bahkan transfer of culture bagi peserta didik. Sehingga dalam konteks kajian ini ketika yang disampaikan kepada anak didik bias gender maka pola pikir yang terbentuk pada peserta didik juga akan bias gender, begitu pula sebaliknya. Sekolah merupakan lembaga yang berperan penting untuk merubah pola pikir peserta didik termasuk perilakuperilaku yang dianggap bias gender. Oleh karena itu sekolah memegang fungsi yang strategis dalam mempersiapkan peserta didik agar dapat mengembangkan multi 
intelegensinya secara optimal tanpa terkendala oleh nilai-nilai sosial budaya.

Proses penyadaran akan kesetaraan gender melalui pendidikan responsif gender memang harus dimulai sejak dini kepada tiap individu, mulai dari usia bayi, melalui perlakukan yang tidak disriminatif terhadap nilai-nilai kemanusiaan jenis kelamin tertentu. Anak-anak adalah tempat yang tepat dalam menyemai pendidikan responsif gender karena anak-anak memiliki daya serap tinggi dalam berpikir sehingga apa yang diajarkan pada usia dini akan menjadi dasar perilakunya yang akan datang.

Hak asasi manusia (HAM) adalah hak yang melekat pada manusia dan merupakan anugrah sejak lahir dari Tuhan Yang Maha Esa yang perlu untuk dijaga, dilindungi dan dihormati oleh individu, masyarakat maupun negara. HAM berlaku secara universal, tidak memandang suku, agama, gender, etnis. Dalam pasal 17 ayat 3 UUD 1945 yang merupakan salahsatu landasan hukum dalam HAM, dijelaskan bahwa adanya persamaan perlindungan dalam menentang tindakan diskrimiansi. Dengan demikian kedudukan laki-laki maupun perempuan disetarakan dalam bidang pendidikan maupun bidang lainnya. Pendidikan responsif gender dalam lembaga pendidikan di bawah naungan diharapkan mampu memberikan kesadaran dalam diri anak-anak (peserta didik) untuk saling menghormati dan menghargai dalam kesetaraan gender. Sehingga peserta didik di lingkungan sosial akan terbiasa untuk menghormati orang lain dan dapat menghargai setiap orang tanpa membedakan status laki-laki maupun perempuan.

\section{Model Pendidikan Responsif Gender Bagi Anak-Anak}

Dalam model pembelajaran responsive gender dapat dilakukan dengan pendekatan budaya dan cerita rakyat. Biasanya anak-anak menyukai cerita rakyat sehingga melalui cerita rakyat tersebut disisipkan nilai-nilai responsive gender di dalamnya. Oleh karena itu, upaya untuk meminimalisasi kesenjangan gender bidang pendidikan harus diarahkan pada nilai-nilai kearifan lokal salah satunya dengan cerita rakyat yang dapat dikemas melalui media audio visual agar lebih menarik untuk anak-anak.

\section{Kesimpulan}

Gender adalah pembedaan peran, fungsi dan tanggung jawab antara perempuan dan laki-laki yang dihasilkan dari konstruksi sosial budaya dan dapat berubah sesuai dengan perkembangan 
zaman, sedangkan jenis kelamin adalah perbedaan antara laki-laki dan perempuan yang ditentukan oleh perbedaan biologis yang melekat pada keduanya.

Pendidikan responsive gender adalah pendidikan yang mengedepankan keterlibatan secara aktif antar jenis kelamin sehingga tidak ada batasan antara laki-laki dan perempuan. Tujuan dari pendidikan responsif gender yaitu terwujudkan kesetaraan gender sebagai upaya pemahaman agar peserta didik dapat memahami dalam memposisikan peran seorang perempuan maupun peran lakilaki
Anak-anak adalah tempat yang tepat dalam menyemai pendidikan responsif gender karena anak-anak memiliki daya serap tinggi dalam berpikir sehingga apa yang diajarkan pada usia dini akan menjadi dasar perilakunya yang akan datang.

Model pendidikan responsif gender dapat dilakukan dengan pendekatan budaya dan cerita rakyat. Anak-anak biasanya menyukai cerita rakyat sehingga melalui cerita rakyat tersebut bisa disisipkan nilai-nilai responsif gender di dalamnya.

\section{Daftar Pustaka}

Dadang S, Dkk. (1997). Membincangkan feminism:Refleksi Muslimah atas peran sosial kaum wanita. Malang: Pustaka Hidayah.

Hasan, Shadly. (1983). Sosiologi untuk masyarakat Indonesia. Jakarta: Bina Aksara

Mansour Fakih. (2013). Analisis Gender dan Transformasi Sosial. Yogyakarta: Pustaka Pelajar.

Miles, M.B., and Huberman, A.M., (1987), Qualitative Data Analysis: A Sourcebook of New Methods, Newbury Park: Sage Publication.

Moleong J. Lexy. (2000). Metode Penelitian Kualitatif, Bandung, PT Remaja Rosda Karya,

Nugroho, Riant. (2011). Gender dan Strategi Pengarus Utamaannya di Indonesia.

Yogyakarta: Pustaka Pelajar.

Silalahi, Ulber. (2006). Metode Penelitian Sosial. Jakarta: Unpar Press.

Spradley, J. (1997). Metode Etnografi, Yogyakarta: PT. Tiaara Wacana

Sugiyono. (2012). Metode Penelitian Pendidikan: Pendekatan kuantitatif, kualitatif, dan $R \& D$. Bandung. Alfabeta.

Sutopo, H. B. (2006), Metode Penelitian kualitatif, Universitas Sebelas Maret Press, Surakarta.

Umar. (2001). Argumen Kesetaraan Gender. Jakarta: Paramadina.

Wibowo, Agus. (2012). Pendidikan Karakter Usia Dini. Yogyakarta: Pustaka Pelajar.

Wibowo, Dwi Edi. (2010). Sekolah Berwawasan Gender. Muwazah. 